DOI: https://doi.org/10.24867/08FA08Causevic

\title{
REVITALIZACIJA INDUSTRIJSKOG OBJEKTA KOŽARE U KREATIVNE RADIONICE
}

\section{REVITALIZATION OF AN INDUSTRIAL LEATHER FACTORY INTO CREATIVE WORKSHOPS}

\author{
Abdulah Čaušević, Fakultet tehničkih nauka, Novi Sad
}

\section{Oblast - ARHITEKTURA I URBANIZAM}

Kratak sadržaj - Tema rada se odnosi na razmatranje $i$ rešavanje problema u kojem se nalazi nekadašnja fabrika kože u Almaškom kraju, u Novom Sadu. Kroz analizu istorijata kraja u kojem se nalazi kožara, dolazi se do zaključka da je objekat od velikog kulturološkog $i$ istorijskog značaja. Primerima revitalizovanih objekata na različitim lokacijama, prikazanih u studiji slučaja, može se primetiti način na koji su mnogi svetski biroi $i$ vrlo stručne ekipe arhitekata uspeli pristupiti ovakvom problemu $i$ oživeti, stare $i$ oronule objekte. Analizom trenutnog stanja objekta, šire $i$ uže lokacije, uočljivi su raznovrsni problemi $i$ nedostaci koji se najpre moraju rešiti, a zatim i veliki broj benefita i pozitivnih stvari koje treba istaći $i$ dodatno unaprediti. Vodeći se analizama $i$ prethodno pomenutim istraživanjima, dolazi se do kreiranja idejnog rešenja koje će ponuditi zanimljiv način revitalizacije stare fabrike kože.

Ključne reči: analiza, revitalizacija, reaktiviranje, studija slučaja, idejno rešenje, input.

Abstract - The topic of the paper is to examine and solve
the problem of the former leather factory in Almaty, Novi
Sad. Through historic analsys of the leather factorys'
location, we come to a conclusion that the building is of
huge cultural and historical importance. Through examples
of revitalized buildings on different locations, presented in
the case study, one can notice the way many world-class
bureaus and highly expert teams of architects have been
able to approach this problem and revive old and
dilapidated objects. By analysing the current state of the
building, wider and narrower location, there are various
problems and disadvantages that must be solved first, and
then a large number of benefits and positive things that
need to be emphasized and further improved. Guided by
the analysis and research mentioned above, we come to a
conceptual solution that will offer an interesting way of
reactivating the old leather factory.

Keywords: analysis, revitalization, reactivation, case study, idejno rešenje, input.

\section{UVOD}

Objekti koji su svoju prvobitnu funkciju izgubili, danas bivaju izloženi propadanju.

\section{NAPOMENA:}

Ovaj rad proistekao je iz master rada čiji mentor je bio doc. dr. Mirjana Sladić
Takvi objekti nemaju više svoje korisnike niti korisnički sadržaj koji odgovara savremenim standardima, što dovodi do gubljenja potrebe za njihovim održavanjem.

Tako oni ostaju zaboravljeni bez ikakvog drugog značaja za društvo osim istorijskog. U najgorem slučaju, ovi objekti bivaju srušeni kako bi se stvorio novi prostor koji bi odgovarao savremenim potrebama društva. Veoma je važno prepoznati takve probleme i naći najbolji način kako sprečiti negativne i pogrešne odluke. Mora se težiti ka očuvanju starih objekata, njihovom unapređenju, kako u fizičkom tako i u funkcionalnom smislu. Važno je, pre svega, uočiti njihov potencijal da bi održali svoju, pre svega, istorijsku vrednost.

\subsection{Predmet istraživanja}

Tematika ovog istraživačkog rada tiče se pronalaženja načina za očuvanje i održivost starih objekata bez svoje prvobitne funkcije, a koje vremenom gube na značaju u svom funkcionalnom smislu. Međutim, takvi objekti ostaju značajni u istorijskom kontekstu i potrebno je posvetiti im pažnju. U slučaju ovog master rada, sva istraživanja su bila sa fokusom na glavni predmet, staru fabriku kože u Novom Sadu, i pronalazak najboljeg načina za revitalizaciju istog.

\subsection{Ciljevi istraživanja}

Cilj celokupnog istraživanja i analize problema koji se odnosi na nekadašnju fabriku kože jeste doći do idejnog rešenja koje će obnoviti izgled i usavršiti prostor unutar fabrike, a sve to posmatranjem kroz prizmu normi i pravila arhitektonske revitalizacije, adaptacije i reaktivacije. Cilj je ponuditi ambijent koji će služiti kako korisnicima objekta, tako i celom gradu.

\subsection{Metode istraživanja}

Metod istraživanja objekta ,kožare“ sastoji se iz nekoliko etapa. Te etape su omogućile sagledavanje i analiziranje pređašnjeg značaja lokacije na kojoj se nalazi objekat, samog objekta i njegovog trenutnog, postojećeg stanja, te u kombinaciji sa istraživanjem svetskih primera revitalizacije i reaktivacije objekata slične namene u prošlosti, dovodi do finalnog idejnog rešenja.

\section{TEMA I SADRŽAJ RADA}

Tema rada jeste pronalazak najboljeg načina za rešavanje problema u kojem se nalazi nekadašnja fabrika kože.

Kompletan rad čini istraživački i tehnički deo.

Istraživački deo objedinjuje mnoge analize: 
- Analiza značaja naselja i kraja kroz istoriju, koja nam pruža saznanje o važnosti lokaliteta i objekta po čitav grad i društvo u njemu.

- Analiziranje trenutnog stanja u kojem se nalazi objekat.

- Istraživanje studija slučaja i osnovni kriterijumi odabira revitalizovanih objekata sličnog istorijskog karaktera, zarad pronalaženja pristupa rešavanju problema i načina revitalizacije objekta bivše fabrike kože.

- Analiziranje trenutnog stanja u kojem se nalazi objekat.

- Analiza idejnog rešenja u vidu predstavljanja koncepta revitalizacije kožare, njegovog obikovanja i delovanja u okruženju i programskog sadržaja.

Na kraju, tehnički deo rada obuhvata grafičke crteže novoprojektovanog idejnog rešenja, 3D vizualizaciju u vidu prikaza odabranog dela enterijera objekta kao i prikaz čitavog kompleksa.

\subsection{Istorijat Almaškog kraja}

U neposrednoj blizini centra Novog Sada nalazi se jedno osobeno gradsko područje koje je oduvek karakterisao seoski način života. Almaški kraj, kao jedan od najstarijih delova sadašnjeg Novog Sada, nastao je naseljavanjem Petrovaradinskog šanca stanovnicima sela Almaš.

Doseljeno srpsko stanovništvo sela Almaš čuvalo je svoju seosku tradiciju i običaje i nije prihvatilo tek tako lako novotarije i građanski život sugrađana iz drugih delova grada [1].

Početkom 20. veka izgrađeno je i više tzv. građanskih prizemnih kuća, a nešto kasnije i nekoliko stambenih višespratnica, i nekoliko manjih industrijskih pogona (Svilara, kožara...) [2].

U srcu Almaškog kraja ostala je sačuvana nekadašnja kožara, u kojoj su još od 80-ih smešteni magacin i radionice Srpskog narodnog pozorišta.

Objekat je vrlo dobro održavan, te uz mala ulaganja može biti prilagođen za različite javne sadržaje [2].

\subsection{Analiza postojećeg stanja objekta}

Trenutno stanje objekta u fizičkom smislu nije na zavidnom nivou, međutim funkcija objekta je promenjena, te objekat i od 1980. godine do danas služi određenim korisnicima, odnosno Srpskom narodnom pozorištu u vidu radionica i magacinskih prostora za članove istog.

Čitav kompleks, kao jednu celinu čini objekat starije gradnje nekadašnje fabrike, manjih gabarita i jasno uočljivog lošijeg fizičkog stanja, kao i objekat novije gradnje, većih gabarita koji je kasnije dodat i koji se lepi uz južnu stranu starije strukture.

Na parceli su dodati i manji objekti poput magacinskih prostora, skladišta i prijavnice na samom ulazu u dvorište.

Na sl. 1. prikazano je trenutno stanje odnosa starog sa novim pridodatim objektima.

Primetna je značajna degradacija fasade, posebno na starijem delu objekta. Počev od dna građevine pa sve do polovine spratne visine prizemlja, da se primetiti da je malterski sloj u velikoj meri opao, te da je fasadna obloga ogoljena sve do same opeke i konstruktivnih elemenata.

Na sl.2. prikazana je vidna degradacija fasade starog dela.

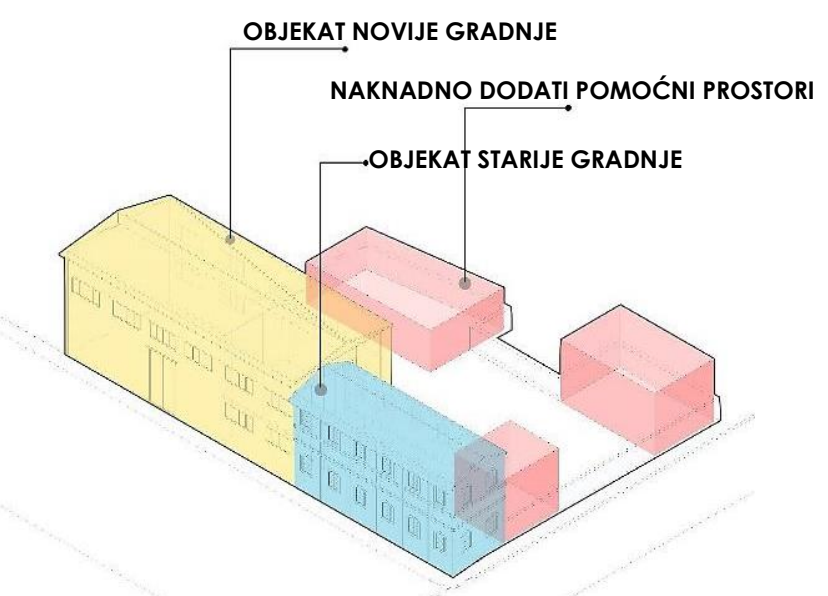

Slika 1. Trenutno stanje odnosa starog sa novim pridodatim objektima

Enterijer objekta je poprilično bolje očuvan odnosu na eksterijer. Obloge zidova, podova, plafona kao i konstrukcija objekta su u velikoj meri sačuvane. Zanimljivo je da enterijerom dominira ogoljena čelična skeletna konstrukcija, koja je vrlo specifična za ovakav objekat.

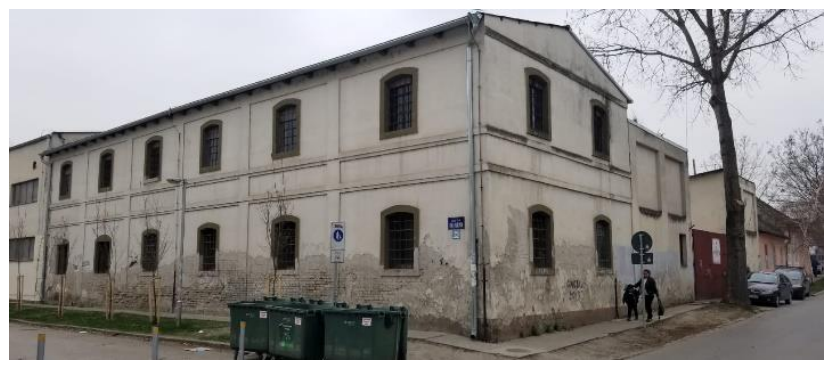

Slika 2. degradacija fasade starog dela

$\mathrm{Na}$ slici 3. je prikaz trenutnog stanja enterijera i čelične konstrukcije.

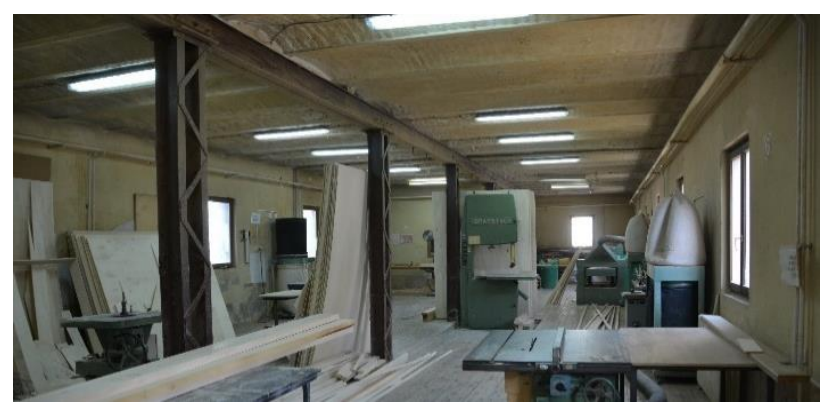

Slika 3. trenutno stanje enterijera i čelične konstrukcije

\subsection{Studija slučaja - Osnovni kriterijumi odabira}

Uz odabir po sadržaju, odabir po oblikovnosti kako enterijera tako i eksrerijera je još jedan od bitnih kriterijuma po kojima je teklo istraživanje. Jasan kontrast između onog što je staro i novo jeste način lakšeg uočavanja onog što je dodato i onog što je originalno, odnosno onog konstantnog i nepromenljivog tokom istorije sve do danas.

Takođe, nove oblikovnosti u enterijeru ili eksterijeru, odnosno uz stari objekat ili u istom, govore o načinu na koji se dolazi do oživljavanja starih objekata od istorijskog značaja.

Ova dva "arhitektonska" kriterijuma po kojima je teklo traganje za slučajevima u neodvojivoj su vezi sa sociološkim aspektima samog društva. 


\subsection{Analiza idejnog rešenja}

\subsubsection{Izgled i delovanje objekta u skladu sa okruženjem}

Parcela na kojoj se nalazi nekadašnja fabrika kože je u neposrednoj blizini postojećeg objekta Kulturnog Centra Svilara koji je nedavno revitalizovan. Svilara samim tim direktno vizuelno, prostorno i sadržajno utiče na način revitalizovanja stare kožare. Ova dva objekta bi po uzoru na prošlost, u budućnosti trebala biti usko povezana i uzajamno delovati u kulturološkom smislu.

$\mathrm{Na}$ sl. 4. prikazan direktan uticaj Kulturnog Centra Svilara na objekat kožare.

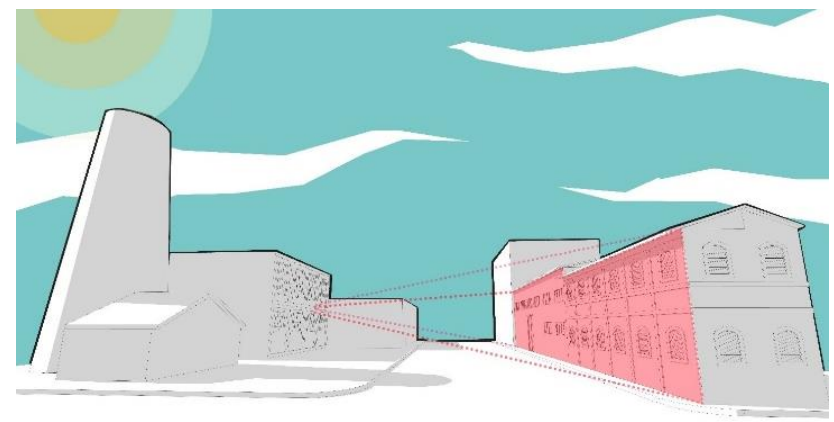

Slika 4. Uticaj Kulturnog Centra Svilara na objekat kožare

Težnja je zadržati autentičan izgled starog dela fabrike, uz manja ulaganja u pospešivanju izgleda, u vidu poboljšanja ruinirane fasadne obloge i prozora. Dok kasnije pridodati objekat, većih dimenzija, koji se lepi uz stariji deo, pruža mogućnost anamorfoze.

Zbog prethodno pomenute bliskosti Kulturnog Centra, dolazi se do ideje otvaranja fasade u vidu procepa, radi bolje vizuelne konekcije i kooperacije između unutrašnjeg „privatnog“ prostora unutar parcele, sa ,javnim“ prostorom trga ispred Svilare. To što uzajamno deluju, čini da se prostor ne zatvara $u$ jedinstven, kompaktan $i$ nepromenljiv sistem, već mu se pruža mogućnost za nove doprinose $u$ vidu raznovrsnih aktivnosti.

Ovim postupkom se takođe dozvoljava Sunčevoj svetlosti da duboko prodre kroz srž objekta i na taj način pruži veliku količinu prirodnog osvetljenja.

$\mathrm{Na}$ sl.5. prikaz procesa otvaranja fasade na novijem delu kožare.

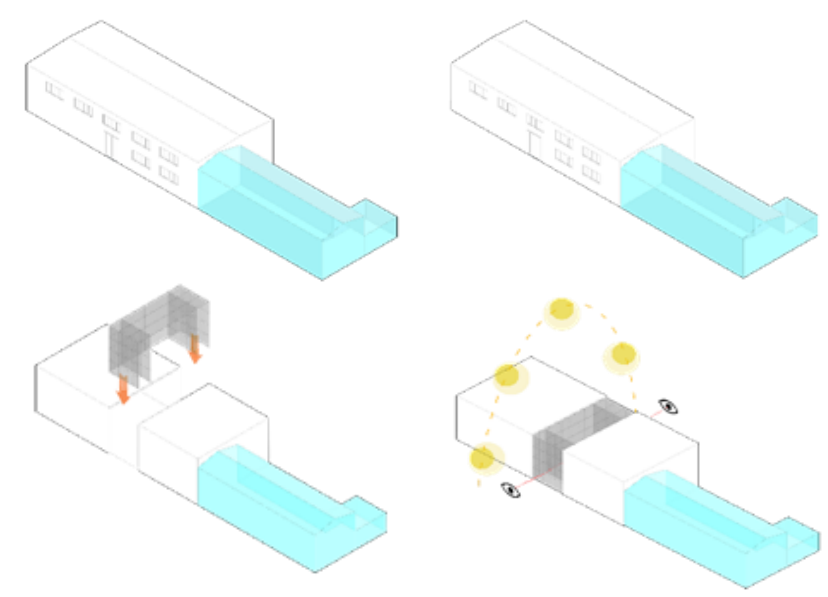

Slika 5. Proces otvaranja fasade

\subsubsection{Programski sadržaj}

Objekat je projektovan tako da služi kako korisnicima, tako i poosetiocima. Prostori unutar objekta izdeljeni su na tri celine. Jedna celina pripada galerijskom prostoru, druga prostoru za kreativne radionice i treća celina pripada administraciji. Svaka od tri nabrojene celine su u međusobnoj korelaciji.

Veliki galerijski prostor otvorenog tipa omogućuje raznovrstan sadržaj. U zavisnosti od potreba, može služiti kao mesto izlaganja kreativnih radova proizvedenih unutar samog kompleksa ili eksponata i umetničkih dela donesenih sa strane. Takođe, veliki gabariti dozvoljavaju održavanja raznovrsnih manivestavija, video prezentacija, predstava, mini koncerata i slično.

Konekciju između izložbenog prostora i kreativnih radionica čini veliki stakleni portal. Kreativne radionice se nalaze $u$ prostoru otvorenog tipa koji uz jednostavne modifikacije može odgovoriti različitim potrebama kreatora. Lako pomerljivim panelima, korisnici sami mogu oformiti sopstvene privatne celine za rad Na sl.6. prikazan programski sadržaj u objektu.

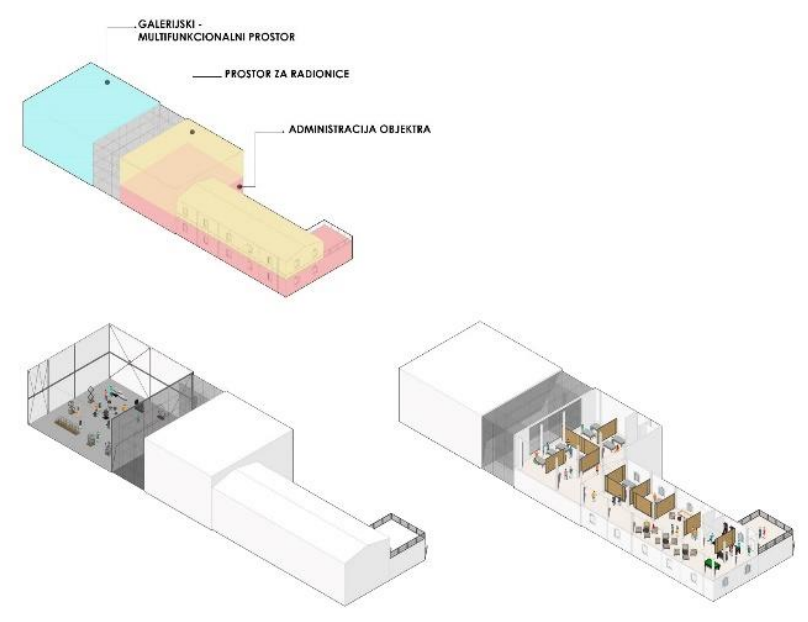

Slika 6. Programski sadržaj unutar objekta

$\mathrm{U}$ prizemlju objekta nalazi se administrativni deo, tehničke prostorije sa ostavama, veliki zastakljeni hol i veliki galerijski prostor. $\mathrm{Na}$ spratu je smešten prostor za kreativne radionice u sklopu kojeg se nalazi i deo za odmor i opuštanje kreatora, odnosno gaming zona, kao i terasa.

\subsubsection{Oblikovanje objekta}

Čiste kubične forme primenjene na dizajnu fabrike Kožare pružaju posmatraču doživljaj novog, čistog, monumentalnog. Ovim dizajnom, kontrast između starog i novog je lako uočljiv.

Čistu belu kubičnu formu po sredini deli velika staklena površina, koja na zanimljiv način, igrom refleksija i propuštanjem Sunčevih zraka unutar objekta, razbija monotonost bele strukture.

Dve velike površine bele boje sa vanjskog javnog prostora trga ili unutrašnjeg privatnog dvorišta svojom oblikovnošću mogu vršiti i ulogu površine za projekovanje video sadržaja. Time objekat dobija na funkcionalnosti kako eksterijerom, tako i unutrašnjim sadržajem.

Na slici 7. prikazan je način oblikovanja objekta. 


\section{LITERATURA}
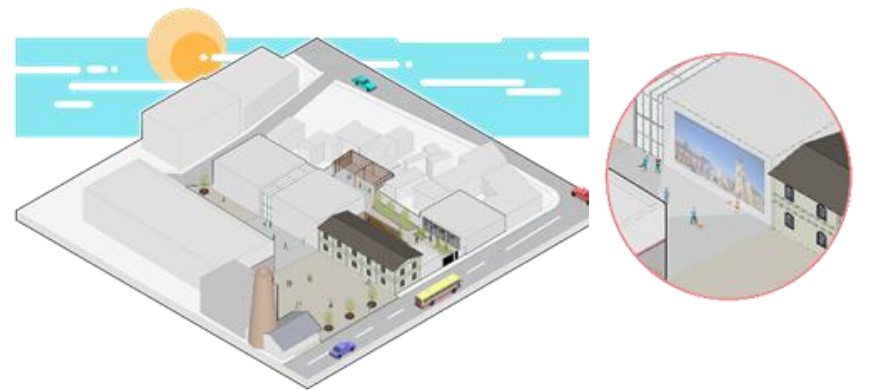

[1] Mirjana Đekić, Maria Silađi, Zbornik Almaškog kraja, Novi Sad 2013. godine, str. 50. [2]. Nastanak i razvoj stambenih palata i vila u Vojvodini oblikovanih u stilu secesije krajem XIX i početkom XX veka - Bogdan M. Janjušević, 2014

[2] Darko Polić, Zbornik Almaškog kraja, Novi Sad 2013. godine, str. 33.

[3] Anica Tufegdžić, Zbornik Almaškog kraja, Novi Sad, str. 116.

\section{Kratka biografija:}
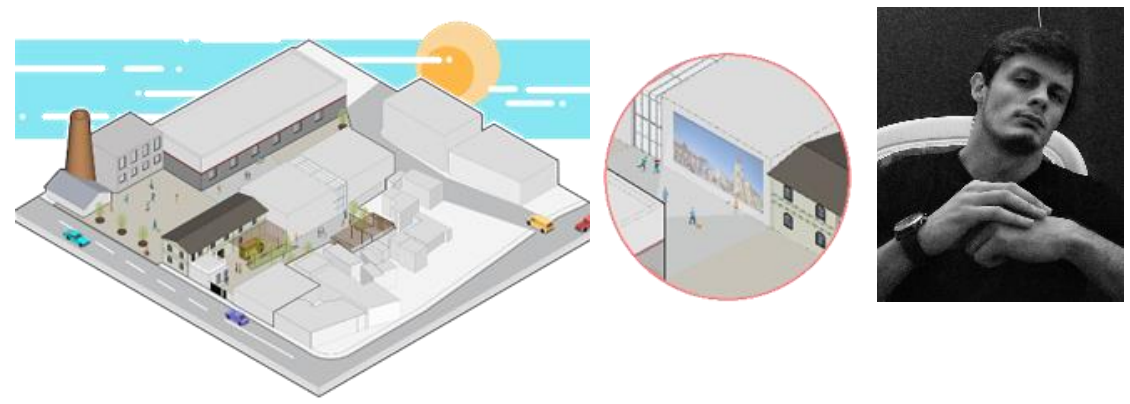

Abdulah Čaušević rođen je u Novom Pazaru 1995. godine. Bachelor rad na Državnom Univerzitetu u Novom Pazaru, iz oblasti Arhitekture - Arhitektonsko projektovanje odbranio je 2018. godine i stekao zvanje diplomirani inženjer arhitekture. Master rad na Fakultetu tehničkih nauka u Novom Sadu na smeru Arhitektonsko i urbanističko projektovanje brani 2019. godine.
Slika 7. Način oblikovanja objekta

\section{ZAKLJUČAK}

Svesni smo činjenice da postoji veliki broj starih objekata od istorijskog i kulturološkog značaja i svesni smo stanja $\mathrm{u}$ kojem se većina njih nalazi. Njihovo propadanje i urušavanje utiče ne samo fizički u smislu lošeg primera očuvanja korena kulture, već i finansijski u smislu utroška sredstava zarad njihovog rušenja i ponovnog stvaranja novih objekata na istom mestu.

Takođe, objekti u takvom fizičkom stanju negativno utiču i sa socijalnih i društvenih aspekata. Takve građevine najčešće budu mesta nastanjivanja beskućnika, mesta prodaje i konzumiranja narkotika, i u velikim slučajevima bivaju izvori zaraze.

Revitalizacijom ruiniranih objekata na koje je vreme ostavilo dubok trag, ne samo da se uklanjaju se sve prethodno navedene negativne posledice, već se tim postupkom objekti u potpunosti ožive i nastave služiti svim građanima. Revitalizovani objekti u većini slučajeva čak uspevaju pospešiti kvalitet života lokalnog stanovništva i povećavaju potencijal drugih objekata $\mathrm{u}$ blizini, koji su takođe na usluzi građanima. 